\title{
A Study of the Cultural Ambiance Delineated in Suniti Namjoshi's Select Poems in the Light ofher Meditative Sensibility which is Gifted with Ironic Perception
}

\author{
Dr. S. Joseph Arul Jayraj \\ Associate Professor of English St. Joseph's College (Autonomous) \\ Tiruchirappalli-620002,Tamil Nadu, S. India.
}

\begin{abstract}
This paper takes into account the cultural ambiance against which Indian women poets have kept the feminine poetic tradition and poetic sensibility vibrant and considers Indian poetry in English by women as the daring assertion of the modern Indian woman. It analyses the cultural ambiance delineated in a few of the poet's select poems in the light of her meditative sensibility which is gifted with ironic perception.
\end{abstract}

Key words: womanhood, culture, the oriental, the occidental, humanoid, patriarchal, verbal opaqueness.

\section{INTRODUCTION}

The Indian women poets in English hail from urban, modernized, intelligent and affluent families with good academic qualification. They are endowed with opportunities for independent career and occupy respected positions in the society. They "deviate from the traditional pattern of Indian womanhood" (Sunanda, 1984, p. 10). Indian women poets in English face certain elements of inevitable tensions in personal life and in social life because they are not flexible, adjustable, submissive, and express strong opinion even before marriage. They rebel against the traditional role of women in the society and struggle to assert their new identity as independent individuals. Thus, they liberate their life from typical Indian feminine psyche (Sunanda, 1984, p. 10).

The cultural position of Indian women in the society and the development of their poetic psyche provide an essential basis for the study of the Indian feminine psyche's contribution to Indian Poetry in English. It can be divided into four categories: a) the Romantics (PreIndependence Poets), b) the New Romantics, c) the Moderns, and d) the New Poets (the PostIndependence Poets) (Sunanda,1984, p.11). SunitiNamjoshi comes under the category of the New Poets. Sometimes, transplantation of women poets from abroad to Indian culture takes place because they get themselves married to the Indians. This category of women poets can be grouped under "Outsider-insider" (Sunanda, "The Background", 1984, p. 12).

In spite of totally unfavourable social ambiance, Indian women poets have kept the feminine poetic tradition and poetic sensibility vibrant from the very beginning. Indian poetry in English by women poets can be considered the boldest assertion of the modern Indian woman.

In response to personal experience, SunitiNamjoshi is "gifted with the unique capacity for ironic perception..." (Sunanda, 1984, p.78). Her translation of the Marathi Poems of Govindagraj is a proof of her Hindu instincts absorbing the Protestant Christian doctrines from her boarding school days. "In consequence I know much more about Christianity than I do about Hinduism", writes Suniti in a personal letter to Sunanda P. Chavan dated 19-07-1978 (Sunanda, 1984, pp. 76, 83). This modern mixture has a more petrifying effect than an enlivening touch. 
The fecundity of Hinduism and the rigidity of Christianity sterilize the fertility of humanity which includes the oriental and the occidental. As a result, her vision becomes characterized by irony rather than by liveliness.

SunitiNamjoshi born in the middle of the $20^{\text {th }}$ century came to her own popularity towards the end of the century. She combines the spirit of India with the physicality of the Western perceptions. Her education in India from the University of Poona was reinforced with additions from the U.S. and Canada, and it attained its maturity during her professorship at the University of Toronto. Her studentship in English literature got enmeshed into humanity as a resource during her study abroad. Indian spirituality is naturally dove-tailed with the physicality of the Western values and it has transformed the physical into the metaphysical experience.

Her poetical volumes are not very voluminous but are not negligible. Her three volumes viz. Poems, More Poems and Cyclone in Pakistan present her as a poet of extreme delicacy and its opposite, strength. Her softness is armoured in steel.

Human experiences are all social, and plurality and mutuality are their character but their foundation is in the solitary and personal threshold.

\section{ANALYSIS OF THE SELECT POEMS}

Being born in a traditionally Hindu family, she appears to be not deeply rooted in her faith. She does not appear to be a fanatic, but a liberal Hindu. She is able to question her faith from a Protestant perspective. It need not be considered the betrayal of one's faith, but her openness to other faiths:

'Graven Images'

For friends who asked me whether the gods I worshipped

Were made out of flesh or made out of stone

The phrase 'Graven Images'may refer to Idolatry. In other words, it is known as worship of idols.It is a pejorative term which expresses contempt or disapproval for the worship of an idol.

First, the squat, minotaur, toad monster

He weighs 2 tons. He is made

out of stone. He has grown so heavy,

so extremely strong, that he cannot move.

You could run about naked. You could tickle

his nose. If he could lift his paw,

he'd probably kill,

But you're probably safe.

He cannot move. Caress his flanks,

and this is his wife,

also of stone. She loves no one. (Suniti, 1982, pp. 61-70)

First, in strength training, 'the squat' refers to a short, fat, ugly, repulsive, emotionless, lethargic and passion-dry animal. God is squatting like a hungry man-eater. He is ready to jump but incapable of jumping because he is kept down by the weight of a couple of stones. His throbbing flesh has become hard stone - static with no movement. Life is lifeless and therefore 
deathless which is no consolation. The partner-wife instead of emitting 'love' as symptom of life is also petrified into its opposite 'lovelessness' which signals 'lifelessness'.

The word 'Minotaur', in Greek mythology, refers to "a species of humanoid bulls, appearing to be about eight feet tall. They walk on their hind legs and carry a variety of massive axes. ... Kratos can kill them by thrusting a sword in their open mouths and at the back of their heads. The 'toad monster' is an abominablecreature" (http://godofwar.wikia. com/wiki/ Minotaur).The whole thing is metaphysically enshrined in the classical-mythological 'minotaur' - the man-eater, hungry-killer and taker of lives in the labyrinthine maze. But the killer is getting killed, and the human-beast signifies a complex of life and death. The 'stone' image here does not stand for firmness or rigidity but stands for 'lovelessness' which is seen earlier also as 'lifelessness'.

The phrase "He weighs 2 tons" implies the fact that the stone-god is incapable of passionate mobility. The concluding line of the poem refers to the stone-wife of the stone-god. "She loves no one", refers to the fact that the stone-wife of the stone-god is forced into obedience to a husband by outmoded patriarchal traditions. Even the tears are 'stones', rounded into pebbles. The rock, which is desensitized from 'rain' and 'wind', contrasts with 'stone' and 'pebbles'. Unlike Shelley's “Ozymandias”, here, one can see the 'smile' in the place of the 'wrinkled lip'. It needs long years, thousands to alter his 'lordship's' smile. Humanity intrudes into the inhuman and into the non-human by 'stroking' and 'petting' and 'kissing' the stone image.

My idol, my pretty one, weep stone

tears, no one is watching.

They will think they are pebbles.

Every night his godship recedes, inches

into rock in the wind and rain.

It will probably take him 6,000 years

7,000 years, to alter his smile, to erode his nose. Human beings

help, their stroking and petting,

their persistent kissing.

His priests rub him down

in butter every day. (Suniti, 1982, pp. 61-70)

The second poem induces the following thoughts in the minds of the readers. In the wind and the rain, leaves and flowers are moved, and participate in the romantic dance, but here is the idolized man who turns into rock oblivious of the romantic drama. He is no longer human because he does not care to stroke, pet and kiss which are acts of passion and love. The passionless man is traditionally adored like the idols in a Hindu temple.

Under the stonetree of which the leaves are made of stone, a man lies asleep. Even his lashes are made of stone. Sometimes an ant will cross an eyelid.

No music moves. This is a man who was probably loved and thus preserved. (Suniti, 1982, pp. 61-70)

Even the tree is constituted in stone. Even its leaves are made of stone. Under its shade, a man is asleep. Even his lashes are made of stone. Even the sound of music does not sound movingly. 
The man is only 'asleep' and not dead. Love envelops him and preserves him alive and the 'stoneliness' of the stone does not prevail and life of humanliness prevails over stone. In this poem, the term 'stone' is repeated thrice because the central image is that of stone. The phrase, 'was probably loved', implies that the idol-like man never loves his wife.

And what's her history?

A blank, my lord.

Twelfth Night, II, iv

The suns slip past,

in the daylight one is tired,

but do not weep. As you sit

very still and turn into stone,

envy no one,

not the girl made of grass,

nor the girl made of straw,

You have your dignity, but their laughter

and delight can offend none. (Suniti, 1982, pp. 61-70)

Shakespeare's Twelfth Night offers a semi-serious motto to the poet to what her meditations are in the fourth poem. Life's 'envy' stills the dynamic and lends the 'stoneliness'. Will it lead to optimism or pessimism? One can usurp the positivism in the metaphysics of personal dignity. The physical becomes the metaphysical, and life with all its boredom and exhaustion can still be squeezed to spit out 'delight', however hard-won it can be.

The opening lines of the poem "And what's her history?/ A blank, my lord", which are a quote from Twelfth Night, Act II, Scene iv, are considered to be the crux of the poem because these lines reiterate the main theme, which is recurrently mentioned in the poems taken for analysis. That is, the woman does not matter at all. But the poet reminds the woman of the fact that every woman has her dignity and her "laughter and delight can offend none" because she has every right to be treated as a dignified human being. The poet encourages women to rebel against the conventional role of women in the society and struggle to assert their new identity as independent individuals. Thus, the poet expects the women to liberate their psyche and life from typical Indian feminine psyche and life style.

\section{CONCLUSION}

SunitiNamjoshi's uniqueness as a poet is her composite fusion of the Western and the Eastern experiences, the fusion of Christian and Hindu sensibilities making her poetic vision worthy of attention by her readers. Her poems communicate before they are understood, because of her "inwardness" in imbibing the delicate intricacies of the genius of the English language.

Her poems have verbal opaqueness that makes it difficult to paraphrase them. If one asks what they mean, they sound like the music of Orpheus. She asks her readers to read them again. They don't tell as much as they mean. They are unparaphrasable, but look at life from new pair of eyes and therefore they have a new perspective and do not starve the curiosity of the reader, making SunitiNamjoshi one of the major minor poets anthologized. She does not preach but does reach the reader's sensibilities without disappointing.

In all the poems taken for analysis,the poet attacks the inhuman behaviour of the male partners towards their female partners under the guise of attacking the idol of the Hindu gods. At the surface level, the poems taken for analysis appear to be echoing the poet's meditative 
sensibility, but at the deeper level, the poems argue vehemently for the rights of women which are denied to them by the male members of the society who are brought up in outmoded patriarchal traditions. Thus, SunitiNamjoshi's poetry evinces the unusual phenomenon of meditative sensibility which is gifted with ironic perception.

\section{References}

Chavan, P. Sunanda. (1984). The Fair Voice: A Study of Indian Women Poets in English. New Delhi: Sterling Publishers Pvt. Ltd.

King, Bruce. (1987). Modern English Poetry in English. New Delhi: OUP.

Namjoshi, Suniti. (1982). The Authentic Lie. “Graven Images”. New Burnswick: Fiddlehead Poetry Books.

Wikia. (Video Games) <http://godofwar.wikia.com/wiki/Minotaur> 09-11-2014. 